\title{
UMBATRA
}

Indonesian Journal of Anthropology

Volume 4 (2) Desember 2019 || eISSN 2528-1569 | pISSN 2528-2115 || http://jurnal.unpad.ac.id/umbara

DOI : $10.24198 /$ umbara.v4i2.25356

\section{Narasi Populer Indonesia Pasca Reformasi: Sebuah Kajian Psikokultural}

\author{
Siti Aliyuna Pratisti, Deasy Silvya Sari dan Taufik Hidayat \\ Departemen Hubungan Internasional, FISIP, Universitas Padjadjaran \\ aliyunapratisti@gmail.com
}

\begin{abstract}
Studies on Indonesian politics of identity after the reform present discussions on conflict-prone identities. Among them are conflicts based on multiculturalism; such as ethnicity, religion, and the relationship between minorities and majorities. Drawing at the current popular narratives in the written material and movies, this article aims at explaining identity-based conflicts in Indonesia, in particular a group trauma related to identity conflicts in Indonesia. Using psychocultural narrative theory, this article examining various cultural elements of the narratives, such as language, religion, social practice, and music and how it reflects the identity and conflict narrative in Indonesia after the reform. This article suggests that the current popular narratives offers the nuances of 1) bringing the Chinese-Indonesian identity back to the Indonesian political space, 2) presenting a new narratives of the 1965 tragedy using the perspective of the victims, and 3) presenting a narratives on religion based-conflicts.
\end{abstract}

Keywords: multiculturalism, psychocultural narrative, identity conflict

\begin{abstract}
Abstrak
Kajian tentang politik di Indonesia pasca reformasi menghadirkan lanskap kajian identitas yang rentan konflik. Salah satunya adalah ancaman konflik terkait isu multikulturalisme, baik dalam dimensi etnis, agama, juga hubungan antara minoritas dan mayoritas. Artikel ini mengkaji ulang konflik identitas di Indonesia pasca reformasi. Berbagai elemen budaya material seperti bahasa, agama, praktik sosial, musik, literasi, ataupun bentuk budaya populer lainnya, diurai menggunakan sudut pandang teori narasi psikokultural untuk menjelaskan aspek trauma kolektif dalam konflik identitas di Indonesia. Artikel ini ditulis sebagai hasil studi literatur yang membandingkan literatur populer yaitu sastra dan film sebagai cerminan narasi konflik identitas di Indonesia pasca reformasi di Indonesia. Simpulan artikel ini adalah, narasi populer terkait identitas yang hadir di era pasca reformasi adalah: (1) narasi multikulturalisme yang mendorong pengakuan kembali identitas Tionghoa dalam ruang politik di Indonesia; (2) narasi pembaharuan terkait tragedi 1965 dengan menghadirkan sudut pandang korban; dan (3) narasi mengenai konflik antar agama.
\end{abstract}

Kata kunci : mulltikulturalisme, narasi psikokultural, konflik identitas 


\section{Pendahuluan}

Masuknya beragam agama ${ }^{1}$ ke Nusantara ${ }^{2}$ menjadikan Indonesia sebagai salah satu negara terkaya dalam hal keragaman etnis, ras, serta agama. Identitas kebangsaan bagi Indonesia adalah multikulturalitas yang diikat dalam sebuah gagasan komunitas imajiner (Anderson, 1991). Pada konteks ini, Anderson menguraikan bahwa imaji tentang kebangsaan merupakan hasil dari interaksi antar identitas yang membayangkan diri sebagai sebuah bangsa. Namun, dalam perkembangannya, multikulturalisme di Indonesia menghadapi beragam tantangan.

Sejarah Indonesia mencatat bahwa terdapat bentuk kebijakan pemerintah yang bertentangan dengan gagasan multikultural, antara lain kebijakan penggantian nama bagi etnis Tionghoa melalui Instruksi Kabinet Presidium No. 127/U/ Kep/12/1966, dan Keputusan No. 240/1967; juga, penguasaan elit politik oleh etnis Jawa merupakan bentuk represi identitas yang terjadi di Indonesia pada masa Orde Baru. Kebijakan ini bukan tanpa kritik, slogan "Persatuan Nasional" yang diusung oleh Orde Baru dipandang telah menghilangkan esensi keberagaman Indonesia dan menafikan keberadaan berbagai bentuk identitas (Soedjatmoko, 1972). Coppel (1994) memberikan pandangan lain bahwa kebijakan penggantian nama memiliki dampak positif pada bangun rasa kebangsanaan etnis Tionghoa sendiri untuk menjadi Indonesia. Pandangan ini sejalan- dengan uraian Wang (1976) tentang akomodasi sosial kultural unik yang dialami etnis Tionghoa dalam perjalanannya menjadi bagian bangsa Indonesia.

Bersandingan dengan dinamika etnis Tionghoa di Indonesia, konflik identitas pasca reformasi juga muncul dalam ranah politik dan penguasaan sumber daya alam. Etnis Jawa yang selama masa Orde Baru menjadi patron sekaligus pemegang "tatanan" politik, mendapatkan tantangan dari identitas daerah (atau dikenal dengan istilah "putra daerah") yang meminta akses lebih luas pada sektor politik dan sumber daya alam. Melalui reformasi birokrasi dan pemerintahan di Indonesia pada 1998, patrimonialisme Jawa berakhir. Namun, masa peralihan (antara 1998 hingga 2000) memunculkan ketegangan antar etnis di berbagai daerah di Indonesia, terutama tergambar pada pemilihan umum daerah (Beittinger-Lee, 2009). Melalui gambaran ini, patrimonialisme dan "narasi persatuan" yang diberlakukan selama masa Orde Baru beralih menjadi akar konflik sosial pasca reformasi ${ }^{3}$. Beragam narasi identitas yang telah lama direpresi, muncul kepermukaan dan berbagi ruang politik dengan kelompok mayoritas. Pada kondisi inilah hadir bentuk pergesekan sosial antar identitas dan menjadi persoalan utama bagi bangsa Indonesia. Reformasi Indonesia 1998, bukan hanya merombak sistem pemerintahan, tapi juga relasi sosial antar identitas di Indonesia. Kebijakan desentralisasi pemerintahan telah memberikan ru-

1 Fakta alamiah menunjukkan bahwa sebuah bangsa yang dikelilingi oleh perairan memiliki fleksibilitas dalam menerima perubahan daripada bangsa yang berada di pelosok daratan. Fleksibilitas ini hadir karena masyarakatnya secara intens berhubungan dengan dunia luar, salah satunya melalui perdagangan yang merupakan sarana utama persinggungan antara satu masyarakat dengan masyarakat lain (Van Den Berg, 1952). Pada perkembangannya, pengaruh Hindu dan Buddha surut sejalan dengan runtuhnya Majapahit yang kemudian memunculkan kerajaan Demak sebagai pusat politik sekaligus pusat penyebaran Islam di tanah Jawa. Namun, penyebaran Islam di Jawa tidak lantas menihilkan tradisi Jawa yang telah kental dengan pengaruh Hindu-Buddha, ditambah dengan masuknya Kristianitas yang diperkenalkan oleh bangsa Eropa. Hal ini membuat agama di Nusantara berkelindan dan tumbuh secara berdampingan sehingga menghadirkan wajah Indonesia yang multikultural.

2 Penyebaran agama di Nusantara juga terangkum dalam Gonda (1975) yang menjelaskan persinggungan agama di Nusantara dalam gambaran yang lebih konfliktual. Penjelasan Gonda memberikan gambaran tentang sifat alamiah politik-agama di Asia Tenggara termasuk Nusantara. ${ }^{3}$ Era reformasi di Indonesia ditandai dengan jatuhnya rezim Orde Baru di bawah pimpinan Soeharto pada 1998. 
ang politik bagi beragam identitas. Namun, represi yang berlangsung selama Orde Baru, telah menghilangkan narasi keberagaman dalam masyarakat Indonesia. Alhasil, multikulturalisme menghadapi hambatan lainnya, yaitu intoleransi. Beberapa kasus yang mengemuka pasca reformasi mengacu pada bentuk intoleransi, antara lain kasus pembakaran musholla di Tolikara (Papua) (Juditha, 2016) juga pembakaran Vihara di Tanjung Balai, Asahan (Sumatera Utara). Selain itu, sejarah kebangsaan pun tercoreng dengan adanya konflik atas dasar identitas terkait hilangnya akses hutan bagi masyarakat Dayak di Kalimantan, juga bentrok warga asli dengan warga transmigran di Lampung (Hawkins, 2009; König, 2016). Konflik identitas ideologis 1965 yang mencuat kembali, menjadikan Indonesia berhadapan dengan permasalahan identitas yang semakin pelik.

Bercermin pada persoalan identitas inilah, artikel ini membahas konflik identitas di Indonesia dengan menggunakan narasi psikokultural sebagai kerangka teoritis untuk mengurai konflik identitas di Indonesia. Tanpa menihilkan penelitian terdahulu terkait konflik identitas di Indonesia (Abdullah, 2010; Coppel, 1994; Thung, 2012), artikel ini mencoba menggali aspek narasi psikokultural (Ross, 2007) dengan mengajukan sebuah pertanyaan: bagaimana konflik identitas digambarkan dalam narasi populer pascareformasi? Studi literatur berbagai elemen budaya populer terutama sastra dan film pasca reformasi, menjadi data primer untuk mengkaji narasi psikokultural di Indonesia. Pemilihan sastra populer mengacu pada perkembangan sastra populer dan film Indonesia pasca reformasi yang banyak mengangkat persoalan identitas. Adapun karya sastra dan film yang dimaksud adalah yang terbit pasca 1998 hing- ga memasuki dekade 2010an, dengan mengangkat sastra dan film terkemuka yang mengangkat narasi identitas (baik konflik ataupun konstruktif) ke tengah-tengah masyarakat.

\section{Kajian Pustaka}

\section{Narasi Psikokultural dan Ingatan Kolektif}

Sebuah bangsa memilih traumanya sendiri (Ross, 2007). Trauma tersebut terekam sebagai ingatan bersama dan kadang digunakan oleh kelompok tertentu sebagai instrumen kepentingan untuk memicu atau melanggengkan konflik. Pada uraiannya, Ross mencontohkan bagaimana ingatan kolektif membentuk konflik identitas antara Jepang dan Tiongkok, yang relasi kedua negara tersebut senantiasa dibayang-bayangi tragedi pembantaian di Nanking pada 1939. Ketika Jepang dan Tiongkok terlibat dalam konflik perebutan klaim Pulau Senkaku, ingatan akan tragedi Nanking mengemuka kembali dan mempercepat eskalasi konflik. Hubungan Palestina dan Israel dibangun atas narasi kuno tentang tanah yang dijanjikan sehingga konflik teritorial ini selalu kembali tertarik dalam narasi identitas agama. Trauma juga hadir dalam konteks hubungan Sunni dan Syiah yang narasinya dilanggengkan melalui peringatan peristiwa Karbala (Ross, 2007).

Sedangkan di Indonesia, terdapat sebuah trauma sejarah dengan landasan konflik ideologi, yaitu tragedi ' $65^{4}$ yang memecah persatuan bangsa. Tragedi ' 65 kemudian menjadi landasan bagi kelahiran pemerintah Orde Baru, sehingga selama 32 tahun rezim tersebut berkuasa, legitimasi politik didasarkan pada ketakutan akan adanya bahaya laten kebangkitan Partai Komunis Indonesia (PKI). Hasilnya adalah sebuah "trauma yang dipilih",

4 Tragedi '65 atau tragedi 1965 merupakan kekacauan politik di Indonesia yang disebabkan upaya pengambilalihan kekuasaan oleh Partai Komunis Indonesia (PKI). Narasi ini adalah narasi utama, walaupun terdapat berbagai skenario bahwa ada pihak lain yang terlibat dalam upaya kudeta tersebut. Salah satu skenario yang terangkat menjadi ingatan kolektif masyarakat diurai oleh Roosa (2008) terkait keterlibatan militer dalam kudeta politik. 
karena pada akhirnya, masyarakat Indonesia lebih merekam trauma kekejaman PKI daripada kekejaman kolonialisme. Namun, Adam (2018) menyatakan bahwa pembaharuan narasi sejarah kasus 1965 dapat dilaksanakan melalui pengungkapan sumber baru (misalnya arsip yang sudah bisa dibuka di Amerika Serikat dan China), juga melalui penggunaan metodologi sejarah lisan dengan penguasa atau pemenang tetapi juga dari para korban. Trauma lain terekam dalam ingatan kolektif bangsa Indonesia adalah pemisahan sosial pada masa kolonial yang memisahkan antara pribumi dengan timur asing (Coppel, 1994). Carey (2008) menambahkan, etnis Tionghoa yang kerap ditempatkan pada posisi pengelola (mantri), menghadirkan ingatan konfliktual yang lebih melekat ketimbang ingatan terhadap penjajahan Belanda sendiri.

Benang merah yang menjadi penghubung beragam konflik pada contoh kasus di atas adalah ingatan kolektif yang membentuk narasi psikokultural sebuah bangsa atau kelompok. Ingatan ini merupakan hasil dari konstruksi masa lalu yang membentuk konsepsi lingkaran hermeunetik, yang dalam perkembangannya melahirkan berbagai simbol dan makna baru, sehingga narasi sejarah berubah menjadi narasi psikokutural (Schafer, 1982). Secara definitif, narasi psikokultural dapat dimaknai sebagai kumpulan ingatan (bisa terangkum dalam cerita masyarakat, kesusastraan, musik hingga film) yang di dalamnya terdapat gambaran atas pandangan sebuah kelompok terhadap kelompok lain (Kaufman, 2001). Lebih lanjut, Ross (2007) mengurai sembilan faktor yang mendasari pembentukkan narasi psikokultural, antara lain: (1) metafora atas sejarah masa lalu, (2) adanya ingatan kolektif, (3) pemilihan narasi tertentu untuk dimunculkan (selectivity), (4) ketakutan dan ancaman pada identitas lain, (5) kesamaan pandangan atas tanggung jawab dalam kelompok, (6) narasi kelompok yang kuat dan berevolu- si (berkembang dalam bentuk simbol), (7) adanya penyebaran narasi, (8) evolusi narasi, dan (9) bentuk klaim superioritas moral yang menganggap identitas lain lebih rendah. Faktor-faktor inilah yang menjadi elemen dasar dalam memahami narasi psikokultural dalam sebuah konflik identitas.

Pembentukan sebuah narasi di masyarakat dan budaya memiliki hubungan yang kompleks. Walaupun demikian, kajian narasi psikokultural memiliki tempat dalam ranah studi identitas ketika para pengkajinya berupaya mencari jawaban tentang akar dari konflik antaretnik. Pendekatan ini menawarkan sudut pandang menarik dalam mengkaji relasi berbagai kelompok identitas dengan memberikan penekanan pada sisi emosional dan ikatan psikologis yang terbentuk antar individu dalam kelompok (Bohleber, 2010). Pandangan lain tentang narasi psikokultural dikemukakan oleh Ross (2007) yang menggambarkan bahwa narasi psikokultural merupakan nilai dan pandangan yang membentuk pilihan dan tindakan sebuah masyarakat. Kaufman (2001) menyatakan bahwa narasi psikokultural dapat dimaknai sebagai kumpulan ingatan yang terangkum dalam cerita masyarakat, kesusastraan, musik hingga film yang didalamnya terdapat gambaran atas pandangan sebuah kelompok terhadap kelompok lain. Hal ini sejalan dengan pernyataan Ross tentang kriteria pembentukan narasi yang didasarkan pada ingatan kolektif. Pandangan lain tentang ingatan kolektif dikemukakan Schafer (1982) yang menarik hubungan tegas antara ingatan kolektif sebuah bangsa dengan narasi psikokultural yang terbentuk. Ingatan ini merupakan sebuah hasil dari konstruksi masa lalu melahirkan berbagai simbol dan makna baru. Proses ini menggambarkan perubahan dari narasi sejarah yang lalu berubah menjadi narasi psikokultural. Pada sebuah konflik identitas, narasi psikokultural seringkali muncul sebagai bentuk agitasi yang mendorong konflik. Konflik Iden- 
titas di Indonesia tidak lepas dari elemen ini. Thung (2012) memberikan gambaran, bahwa konflik identitas tidak dapat dipahami secara sederhana, termasuk konflik sosial dengan latar agama ataupun etnis di Indonesia. Untuk itulah, pandangan terkait kebangsaan dan ingatan kolektif perlu dikaji melalui berbagai faktor yang memengaruhinya.

Narasi psikokultural antar kelompok tidak selamanya hadir dalam bentuk yang destruktif, salah satu contohnya adalah narasi kooperatif etnis Basque di Perancis yang sangat berbeda dengan narasi agresif etnis Basque di Spanyol. Contoh ini menjadi penjelas bahwa identitas merupakan konsep yang cair, sehingga walaupun mengacu pada kerangka etnis yang sama, namun dapat menghasilkan kondisi yang berbeda sesuai dengan dinamika internal dan eksternal etnis tersebut. Pandangan konstruktif dari ingatan kolektif juga dikemukakan oleh Linenthal (2001) yang menggambarkan bahwa walaupun narasi psikokultural dapat menjurus pada konstruksi negatif melalui kehadiran redemptive narrative (menggunakan simbolisasi agama untuk berbagai kejadian yang dialami masyarakat) dan toxic narrative (narasi yang mempertahankan kegelisahan dalam masyarakat), tapi tidak mustahil untuk membangun sebuah progressive narrative yang mengacu pada upaya membangun kembali perdamaian dalam sebuah komunitas. Pandangan lain tentang sisi rekonstruktif dari narasi psikokultural dikemukakan oleh Kelman (1995) yang menggambarkan hubungan eksplisit antara proses perdamaian dengan budaya yang dianut oleh masyarakat. Sebuah konflik, menurut Kelman, dapat diakhiri melalui upaya perubahan narasi psikokultural masyarakat. Hal ini karena narasi digerakkan oleh emosi, maka perubahan dapat dilakukan melalui perubahan pada simbol dan ritual. Ia juga menyatakan bahwa narasi budaya yang kuat seringkali terangkum dalam kejadian se- jarah, pagelaran budaya, hari raya keagamaan, serta dongeng yang diturunkan dari generasi ke generasi (Kelman, 1995). Salah satu contoh nyata bagaimana simbol dapat mengubah narasi dilakukan oleh figur seperti Nelson Mandela yang berhasil mengakhiri narasi apartheid di Afrika Selatan; atau festival insklusif (yang melibatkan penganut Protestan dan Katolik) di Derby, Irlandia Utara, berhasil menurunkan ketegangan antar umat beragama yang tengah berkecamuk. Figur Abdurahman Wahid memiliki tempat yang sama dengan Mandela, sebagai simbol multikulturalisme dan perdamaian antar etnis di Indonesia.

Contoh di atas memberikan gambaran bahwa tidak selamanya narasi psikokultural antarkelompok hadir dalam bentuk yang destruktif, hal itu pula dapat menjadi perekat identitas (seperti kesamaan identitas Asia-Afrika), atau sebagai upaya untuk membentuk narasi kebangsaan. Sebagai contoh, gerakan anak muda Jerman pasca Perang Dunia II yang secara bersama-sama menanggalkan gagasan superioritas ras melalui gerakan musik krautrock ${ }^{5}$, atau narasi adaptif etnis Basque di Perancis yang sangat berbeda dengan narasi agresif etnis Basque di Spanyol, adalah contoh bagaimana narasi psikokultural dapat hadir dalam bentuk yang konstruktif.

Namun, karena kerap dijadikan instrumen demagogi politik, maka narasi psikokultural sebagai pendekatan juga sering digunakan sebagai pendekatan dalam kajian politik dan kekerasan sosial. Argumen lain tentang relevansi narasi psikokultural sebagai sebuah pendekatan dalam analisis konflik identitas dikemukakan oleh Ross (2007).

Selain melalui analisis elemen di atas, terdapat empat indikator utama yang dapat dijadikan landasan untuk memahami narasi psikokultural dalam sebuah konflik identitas, yaitu: (1) penggambaran atas narasi dan metafora

\footnotetext{
5 Istilah yang mengacu pada genre musik populer yang berkembang di Jerman pasca perang dunia II.
} 
tentang bagaimana seseorang serta kelompok memahami keterlibatan mereka dalam sebuah konflik sosial maupun politik, (2) dengan mengungkap narasi tentang ketakutan, ancaman, serta trauma masyarakat yang mendorong terjadinya konflik, (3) mengkaji pertarungan asimetris antara satu narasi dengan narasi lain dalam sebuah konflik identitas (melalui represi terhadap narasi lawan), dan (4) menguraikan konstruksi pembentukan dan penyebaran narasi psikokultural dalam masyarakat (Roy, 1994). Keempat indikator di atas merupakan kerangka yang dapat digunakan dalam memahami sisi emosional yang mendorong terjadinya konflik identitas. Pemahaman atas metafora dan simbol-simbol yang mendorong konflik identitas menjadi sangat penting, karena melalui analisis tersebut faktor emosi yang menjadi penggerak utama dalam konflik identitas. Pada konteks narasi Orde Baru, contohnya, simbol dan trauma 65 digunakan sebagai instrumen untuk mempertahankan narasi konflik.

\section{Hasil dan Pembahasan}

\section{Identitas dalam Narasi Populer}

Kurun waktu dua puluh tahun terakhir, Indonesia memasuki apa yang dikenal dengan istilah era reformasi. Tiga perubahan utama yang memberikan dampak signifikan dalam kehidupan bangsa dan bernegara yaitu perubahan struktur pemerintahan, perombakan kerangka ekonomi, dan pengakuan kembali pada hak kebebasan berpendapat; ketiga perubahan tersebut berimplikasi pada konflik identitas (Haryanto, 2012). Konflik sosial yang terjadi di berbagai daerah seperti Kalimantan dan Maluku Utara; konflik dengan landasan separatisme di Aceh dan Papua; hingga berbagai kasus berlandaskan etnis dan agama, menjadi salah satu persoalan yang dihadapi Indonesia pasca reformasi.

Reformasi pemerintah dan sendi ekonomi tidak bersinggungan langsung dengan nara- si psikokultural, namun keduanya merupakan penjelas utama dalam perubahan pola konflik sosial masyarakat di Indonesia. Perubahan yang ketiga, yaitu reformasi dalam kebebasan berpendapat, akan menjadi struktur utama dalam menjelaskan narasi psikokultural dalam konflik identitas di Indonesia. Pemahaman tentang kebebasan berpendapat dalam media massa, media sosial, sastra dan budaya populer, menggambarkan bagaimana narasi psikokultural sebuah kelompok bersinggungan dengan kelompok lain.

Salah satu yang mengemuka di awal masa reformasi adalah pengakuan kembali eksistensi etnis Tionghoa. Diskriminasi etnis Tionghoa memiliki sejarah panjang sejak masa kolonial yang mengeluarkan kebijakan tegas pemisahan strata sosial dan dalam menginklusifkan etnis Tionghoa (Carey, 2008; Coppel, 1994). Salah satu kebijakan utamanya adalah penggantian nama keturunan Tionghoa menjadi nama Indonesia. Kebijakan sistematis ini memiliki konsekuensi hilangnya identitas Tionghoa secara perlahan. Ditambah pelarangan terhadap perayaan hari besar khas Tionghoa, lebih dari 40 tahun, menjadikan identitas Tionghoa tidak memiliki ruang dalam bangun kebangsaan Indonesia. Di sisi lain, walaupun secara identitas mengalami represi, etnis Tionghoa berhasil menguasai struktur ekonomi Indonesia. Hal ini terjadi secara alamiah karena kebijakan pembatasan ruang dalam pemerintahan, maka etnis Tionghoa mengkhususkan diri pada sektor ekonomi. Namun, lambat laun keterasingan identitas dan dominasi pasar ini berujung pada kebencian terhadap etnis Tionghoa yang meledak dalam tragedi 1998 (Chua, 2003).

Ketika Abdurrahman Wahid (Gus Dur) menjabat menjadi presiden Indonesia, narasi identitas Tionghoa pun mulai berubah. Melalui gagasan multikulturalisme, Gus Dur menginisiasi pengakuan kembali keberadaan identitas Tionghoa dengan memberikan ruang pada 
ekspresi kebudayaan seperti perayaan hari-hari besar keagamaan, serta ritus kultural seperti perayaan tahun baru Imlek (Suryadinata, 2003). Langkah ini menjadi tonggak bagi hadirnya kembali multikulturalisme di Indonesia yang direalisasikan dengan memberikan ruang pada etnis Tionghoa. Kebebasan berekspresi bukan hanya diberikan pada konteks sosial budaya, tapi juga pada bidang politik, yang ditandai dengan hadirnya kembali keturunan Tionghoa di kancah politik-hal yang mustahil dilakukan pada era Orde Baru.

Pandangan multikulturalisme Gus Dur memberi jalan pada perubahan narasi psikokultural identitas Tionghoa di Indonesia. Roy (1994) menyatakan bahwa sekat sosial dapat mendorong sebuah identitas untuk terlibat dalam konflik. Hal ini karena sekat sosial memunculkan keterasingan antarberbagai kelompok yang lambat laun akan berujung pada persepsi ancaman dan ketakutan, sebagaimana yang terjadi pada etnis Tionghoa di Indonesia. Sekat sosial ditambah dengan hadirnya kesenjangan sosial ekonomi cenderung menumbuhkan kecemburuan dan memunculkan stereotipe akan etnik lain, terutama yang dipandang lebih berhasil dalam konteks ekonomi (Haryanto, 2012). Namun, persepsi ancaman pun terkonstruksi dalam benak masyarakat yang notabene adalah mayoritas, yaitu etnis Tionghoa yang eksklusif, ditambah dengan penguasaan sendi ekonomi, memunculkan narasi keterancaman yang kuat di kalangan masyarakat pribumi. Ketika pandangan saling mencurigai telah terbangun, maka dapat dikatakan bahwa sekat sosial telah terbentuk pada kedua identitas tersebut.

Mengacu pada konstruksi psikokultural di atas, kebijakan pemerintah dengan mengakui identitas Tionghoa tidaklah cukup. Perubahan juga harus didorong melalui berbagai narasi identitas yang bersentuhan secara langsung dengan masyarakat. Salah satu bentuknya adalah dengan diangkatnya film-film dengan latar etnis
Tionghoa seperti Ca Bau Kan, juga roman sejarah Soe Hok Gie atau drama berjudul Berbagi Suami pada 2005 yang mengangkat kehidupan etnis Tionghoa ${ }^{6}$. Narasi mengenai Tionghoa dalam novel yang diangkat oleh Shindunata (2007) dalam Putri Cina, atau Dimsum Terakhir karya Clara Ng (2013). Film dan novel inilah yang mampu memberikan dampak yang sangat positif dalam penerimaan kembali identitas Tionghoa sebagai bagian dari masyarakat multikultur Indonesia. Salah satu contoh narasi lain hadir melalui stand up comedy: Ernest Prakoso, seorang komedian, berhasil mengangkat narasi "kecinaan" hadir bersanding dengan narasi budaya lain. Budaya populer memungkinkan keterasingan masyarakat luas terhadap identitas Tionghoa berkurang sedikit demi sedikit, terlebih dalam Soe Hok Gie digambarkan dengan jelas bagaimana awal mula represi identitas dilakukan oleh rezim Orde Lama. Pemahaman sejarah ini sangat penting, baik bagi etnis Tionghoa untuk menyuarakan narasinya, juga untuk masyarakat Indonesia secara keseluruhan guna menghilangkan berbagai prasangka dan rasa keterancaman.

Narasi psikokultural lain yang juga penting dalam peta politik identitas Indonesia adalah narasi identitas yang bersinggungan dengan persoalan agama. Sisi agama yang dogmatis kerap memunculkan narasi keterancaman pada interpretasi lain. Beberapa bentuk konflik identitas keagamaan yang muncul antara lain pandangan mayoritas muslim terhadap keberadaan Ahmadiyah, juga kehadiran aliran Syiah di Indonesia. Tidak kalah peliknya adalah permasalahan antara umat beragama, yang secara nyata tergambar pada bentuk-bentuk pelarangan pembangunan tempat ibadah hingga terjadinya pembakaran rumah ibadah (vihara dan musholla) juga upaya aksi kekerasan di gereja, menjadikan narasi psikokultural antaragama di Indonesia belum sepenuhnya terwujud dalam narasi yang positif. Hadirnya radikalisme

\footnotetext{
${ }^{6}$ Dalam sejarah perfilman Indonesia, cerita rakyat Tiongkok sebetulnya pernah digarap sebelum dan pada masa awal kemerdekaan,namunhilangsejalankebijakanasimilasietnis TionghoadiIndonesia.Beberapadiantaranyaadalah:film Sam PekEng Tay (1931), Gadis Jang Terdjoeal(1937), OhIboe(1938), Penjelundup (1952) dan DiBalikAwan (1963).
} 
menyebabkan benturan antaragama di Indonesia semakin berjalan ke arah yang membahayakan bagi multukulturalisme. Konflik lain muncul dalam persinggungan narasi agama dengan aliran kepercayaan. Aliran kepercayaan seperti Kejawen (Jawa Tengah dan Jawa Timur), Sunda Wiwitan dan Buhun (Jawa Barat), Parmalim (Sumatera Utara), Kaharingan (Kalimantan), Wetu Telu (Lombok), Marapu (Sumba), serta berbagai kepercayaan asli masyarakat Indonesia, belum sepenuhnya dapat dipahami oleh masyarakat luas, sehingga keberadaan identitasnya kerap terasing. Keterasingan pada identitas ini, secara ekstrem dapat berujung pada bentuk pengusiran seperti pada warga Ahmadiyah dan Syiah. Melalui kasus tersebut, persinggungan narasi psikokultural di Indonesia juga berkelindan dengan identitas keagamaan (Rosyid, 2013).

Upaya pencarian solusi berbagai permasalahan agama di Indonesia menjadi semakin sulit dilakukan ketika konflik antaragama dilandasi oleh narasi yang tidak berimbang. Berbagai pelarangan atas sumber bacaan atau diskusi yang bertema Ahmadiyah dan Syiah kerap terjadi karena hadirnya narasi keterancaman dari muslim mayoritas terhadap penyebaran paham-pahamnya. Alhasil, narasi dari kedua bentuk sektarian tersebut tetap direpresi; dan apabila belajar dari represi terhadap etnis Tionghoa, bentuk pembungkaman sebuah narasi identitas hanya akan berujung pada persepsi keterancaman yang rentan menjadi konflik terbuka. Terhadap permasalahan ini, Abdullah (2010) mengakui bahwa kerendahan hati untuk menerima perbedaan persepsi dalam beragama sangat sulit dilakukan terkait dengan dogma agama yang bertentangan dengan relativisme. Namun, mengingat konteks mayarakat yang multikultur, bentuk pluralisme ${ }^{7}$ harus tetap diupayakan. Pandangan ini pun berlaku bukan pada konflik sektarian saja, namun juga pada konflik agama secara keseluruhan; karena hanya dengan memberi ruang pada berbagai pandanganlah, ketakutan dan keterancaman dari sebuah narasi yang asing dapat dikikis sedikit demi sedikit.

Dialog lintas agama dilakukan oleh pemuka agama atau komunitas-komunitas masyarakat yang menginisiasi perdamaian antara agama (contohnya kajian IMPULSE yang berkembang di Yogyakarta). Selain itu, upaya untuk mengikis narasi keterancaman dilakukan pula dengan mendorong berbagai produk budaya seperti film, pameran lukisan, novel dan cerita pendek, juga pertunjukkan musik. Ulama sekelas K.H Mustafa Bisri memamerkan lukisan-lukisan bertema keislaman untuk menampilkan narasi agama yang damai. Demikian pula yang dilakukan oleh Romo Mudji Sutrisno yang menggelar pameran lukisan bertema kristianitas dan perdamaian di sebuah galeri di Pojok Taman Ismail Marzuki. Pada konteks budaya populer, upaya menyuarakan narasi perdamaian lintas agama pun dilakukan, misalnya beberapa judul film Indonesia Bukan Negara Islam (2006), Rumah di Seribu Ombak (2012), juga Tanda Tanya (2011). Bersandingan dengan film, narasi lintas agama juga diungkap dalam novel Madasari (2012) yang mengangkat konteks suara marginal komunitas Ahmadiyah melalui novel berjudul Maryam; sedangkan dalam pertunjukkan musik, pagelaran musisi lintas agama yang menggaungkan multikultural senantiasa disuarakan oleh berbagai komunitas musisi, salah satunya melalui Pagelaran Delapan yang digagas oleh Kelompok Musik Kiayi Kanjeng. Bentuk arus kebudayaan seperti ini patut diapresiasi karena secara tidak langsung, pesan-pesannya akan meresap ke dalam ingatan kolektif masyarakat sehingga rasa ketaku-

7 Pluralisme secara praktis dapat dipahami sebagai: hidup berdampingan walaupun tidak mengakui kebenaran agama lain. Bellamy (1999) menyatakan bahwa "pluralism permeates modern societies, the mixed blessing of their differentiation and openness. The basic pluralist belief affirms there are many moral and non-moral values and that in practice they may prove either inherently or contingently incompatible". 
tan dan keterancaman akan digantikan dengan kehadiran toleransi.

Bersamaan dengan mencuatnya konflik-konflik berlandaskan keagamaan, kehadiran konflik identitas di Indonesia juga berkelindan dengan ruang ideologi politik. Persinggungan ini terkait dengan trauma bangsa yang senantiasa menjadi persoalan pelik yaitu narasi tragedi ' $65^{8}$. Pada awalnya, narasi ' 65 yang hadir dalam ingatan kolektif masyarakat Indonesia merupakan narasi versi pemerintah Orde Baru yang dimunculkan melalui film dan teks-teks sejarah. Pencangkokan ingatan tentang versi kejadian 1965 terus dilakukan selama rezim tersebut berlangsung, tujuannya tidak lain yaitu melanggengkan narasi yang telah disesuaikan dengan kepentingan pemerintah (Tornquist, 2011). Sebuah penjelasan tentang fungsi dasar narasi muncul di sini: pertama sebagai bentuk metafora dan citra yang diperkenalkan kepada individu atau masyarakat tentang konflik politik yang terjadi di dalamnya. Kedua, mengangkat ketakutan atau mempersepsikan ancaman dari sebuah gerakan politik yang dapat kembali memunculkan konflik. Ketiga, narasi menjadi penting karena mengizinkan sebuah kelompok untuk melakukan tindakan tertentu atas kelompok lainnya. Terakhir, keempat, pengulangan narasi ditujukan untuk mengkonstruksi atau memperkuat pandangan masyarakat (Roy, 1994). Mengacu pada poin terakhir inilah kita bisa memahami mengapa bangsa Indonesia memilih narasi '65 sebagai tragedinya, karena legitimasi pemerintahan saat itu, berasal dari penyatuan pandangan masyarakat tentang apa yang terjadi pasca tragedi enam lima.

Namun, setelah rezim Orde Baru runtuh, titik tolak tragedi bangsa ternyata belum berubah. Narasi ' 65 tetap muncul, bahkan dalam jumlah yang masif, sebagai kritik terhadap nara- si yang dimunculkan oleh rezim Orde Baru. Kritik tersebut hadir di opini koran, jurnal ilmiah, buku teks sejarah (yang telah direvisi), bahkan menjadi tema yang sangat populer dalam sastra kontemporer Indonesia pasca runtuhnya rezim orde baru. Pada narasi tandingan ini muncul deretan karya sastra yang bertema '65: Blues Merbabu (Gitanyali, 2012), Amba (Pamuntjak, 2017), Pulang (Chudori, 2013), Kalathida (Adjidarma, 2007), Lubang Buaya (Weiringa, 2003), Nyanyian dalam Kelam (Sutikno, 2010), dan Ia Menangis di Depan Televisi (Putu, 2003), adalah beberapa di antaranya. Sedangkan narasi dalam bentuk puisi, jurnal, dan film, tidak kalah jumlahnya. Bentuk kritik narasi merupakan narasi tandingan yang menyuarakan suara-suara yang untuk sekian lama telah dibungkam.

Munculnya narasi alternatif membentuk kompetisi arus pemikiran dalam masyarakat atau dikenal dengan istilah: drama psikokultural. Secara definitif, drama psikokultural merupakan konflik antar kelompok atas klaim kebenaran pada permasalahan yang belum terselesaikan. Ia lantas bermanifestasi dalam identitas kelompok yang terbentuk bersama pengalaman dan sejarah (Ross, 2007), juga dapat dipahami sebagai sebuah manifestasi yang muncul dalam berbagai elemen budaya material seperti bahasa, agama, praktik sosial, musik, literasi, ataupun bentuk budaya populer lainnya. Persinggungan ini merupakan sebuah dinamika sosial yang tidak dapat dihindari. Dialog antarberbagai narasi bahkan harus didorong sebagai mekanisme alamiah dalam dialektika masyarakat; justru, ketika drama psikokultural direpresi dan ditiadakan dalam konteks kemasyarakatan, maka kita haruslah curiga akan adanya konstruksi nilai yang dipaksakan oleh kepentingan sepihak.

\section{Film dan Sastra sebagai Narasi Psikokul-}

8 Tragedi 1965 merupakan sejarah kelam bangsa yang berujung pada konflik berdarah antara kubu komunisme (PKI) dengan pemerintah berkuasa. Penahanan dan pembunuhan massal yang secara sistematis dilakukan oleh Pemerintah hingga saat ini menjadi ingatan buruk bagi masyarakat Indonesia. Belum adanya rekonsiliasi dari pemerintah menjadikan narasi 65 tetap menjadi persoalan yang mengganjal dalam peta politik di Indonesia. 


\section{tural}

Budaya populer melalui bentuk film dan sastra merupakan sebuah representasi dari ingatan kolektif dan narasi psikokultural masyarakat. Definisi Kaufman (2001) yang menyatakan bahwa narasi psikokultural terangkum dalam gerak budaya masyarakat, tergambar secara nyata dalam film dan sastra pasca jatuhnya rezim Orde Baru, melalui beberapa bentuk, antara lain: (1) bentuk simbolik, yang mengacu pada penggunaan simbol-simbol identitas, baik agama, etnis atau ideologi, dalam pemaparan cerita; (2) bentuk kebiasaan, yaitu penggunaan kisah hidup keseharian yang menggambarkan sistem tradisi yang berdasarkan norma-norma adat yang telah diwariskan secara turun temurun; dan (3) bentuk narasi, yaitu terdapatnya wacana konflik identitas yang dibicarakan dalam alur cerita. Lebih lanjut, analisis konflik identitas dalam narasi populer dapat didasarkan pada analisis empat indikator utama dalam sebuah konflik identitas yang dikemukakan Roy (1994) terkait penggambaran atau metafora atas narasi, yaitu: narasi yang mengungkapkan tentang ketakutan, ancaman, serta trauma masyarakat, relasi antarnarasi, dan konstruksi pembentukan dan penyebaran narasi psikokultural dalam masyarakat. Keempat indikator di atas merupakan kerangka yang dapat digunakan dalam memahami sisi emosional yang mendorong terjadinya konflik identitas. Pemahaman atas metafora dan simbol-simbol yang mendorong konflik identitas menjadi sangat penting, karena melalui analisis tersebut faktor emosi yang menjadi penggerak utama dalam konflik identitas dapat dipahami.

Di Indonesia, perubahan politik 1998 menjadi titik balik dalam narasi psikokultural. Terdapat tiga persoalan identitas yang menjadi permasalahan utama yaitu represi identitas Tionghoa, intoleransi antar umat beragama dan tragedi '65. Tiga persoalan tersebut semakin mendapatkan perhatian dari masyarakat dan masuk ke dalam diskursus publik. Pada kasus Tionghoa, pengembalian hak identitas Tionghoa adalah sebuah upaya mencapai keadilan restitutif dengan mengembalikan hak eksistensi, bahkan memberikan hak politis, bagi etnis Tionghoa di Indonesia. Keadilan sosial politik ini merupakan langkah penting bagi multikulturalisme Indonesia. Bersandingan dengan pengakuan hak, keadilan juga disuarakan melalui berbagai bentuk budaya populer. Tindakan ini merupakan bentuk upaya membangun narasi psikokultural yang konstruktif, yaitu dengan membangun dialog dan pemahaman antara satu pihak dengan pihak lain sehingga toleransi dapat terwujud. Walaupun demikian, narasi psikokultural etnis Tionghoa di Indonesia belum sepenuhnya mencapai perdamaian yang positif. Hal ini disebabkan masih hadirnya trauma dan memori kolektif yang mengacu pada korban tragedi 1998 yang sampai saat ini belum terselesaikan, sehingga ketegangan yang melibatkan etnis Tionghoa masih kerap terjadi.

Reformasi juga memberikan dampak pada narasi psikokultural terkait tragedi '65. Adanya kebebasan berpendapat menyebabkan diskursus tentang sejarah kelam Indonesia dapat diangkat ke ruang publik; sesuatu yang mustahil dilakukan pada masa Orde Baru. Pencabutan status Tahanan Politik ${ }^{9}$ merupakan salah satu upaya mencapai keadilan restitutif. Melalui pencabutan status tersebut, keberadaan masyarakat yang selama masa Orde Baru teralienasi mendapatkan ruang untuk kembali ke dalam ruang kebangsaan. Tentu saja pencabutan status semata tidak akan berhasil apabila tidak diikuti dengan upaya konstruktif melalui pemberikan ruang bagi para korban tragedi 65 untuk bersuara. Berlandaskan kebebasan berekspresi dan berpendapat, keadilan ini diupayakan melalui izin penerbitan berbagai film hingga novel dengan latar tragedi 1965 . Keberadaan nara-

\footnotetext{
${ }^{9}$ Status tahanan politik mengacu pada individu yang terlibat PKI.
} 
si ini sangat penting, yaitu agar masyarakat memahami secara proporsional permasalahan yang terjadi dan tidak mudah termakan propaganda kepentingan politik kelompok tertentu. Namun, sama halnya dengan permasalahan narasi etnis Tionghoa, keadilan bagi pelaku kejahatan tragedi ' 65 belum tersentuh secara nyata. Hal inilah yang menjadikan isu ini masih sensitif dan belum menemui titik selesai; sedangkan konflik identitas terkait identitas agama baru muncul pasca reformasi. Sejarah mencatat bahwa pemboman gereja ataupun kekerasan atas latar agama hadir bersamaan dengan mencuatnya isu-isu terorisme dalam konteks global. Namun, terdapat narasi lain dalam konflik agama di Indonesia, yaitu minimnya pengakuan terhadap narasi keagamaan minoritas. Syiah dan Ahmadiyah adalah bentuk minoritas yang senantiasa teralienasi dari narasi keagamaan Indonesia. Walaupun ada beberapa produk budaya yang mengangkat tentang minoritas tersebut, namun suaranya masih sangat minim. Titik terang pada narasi psikokultural keagamaan di Indonesia adalah dengan disahkannya UU tentang Kepercayaan tradisi. Ini merupakan langkah awal bagi terbangunya narasi yang berimbang sehingga toleransi dapat terwujud.

\section{Simpulan}

Indonesia dan multikulturalisme tidak dapat dipisahkan. Namun, dalam perkembangannya, terdapat berbagai catatan terjadinya konflik antar identitas yang membentuk "trauma" dan "memori kolektif' masyarakat, atau dalam konseptualisasi Ross (2007) dikenal dengan istilah narasi psikokultural. Narasi tersebut hadir dalam berbagai bentuk: sejarah, tradisi hingga budaya populer seperti sastra, musik dan film. Mengacu pada kerangka teoritis, analisis studi pustaka mengantarkan sebuah simpulan sebagai berikut: (1) pembentukan narasi multikulturalisme yang mendorong pengakuan kembali identitas Tionghoa dalam ruang politik di Indonesia; (2) kehadiran narasi pembaharuan terkait tragedi 1965 dengan hadirnya narasi dari sudut pandang korban; dan (3) perhatian pada narasi konflik antar agama, termasuk kekerasan pada minoritas seperti Ahmadiyah.

Identifikasi pembentukan narasi psikokultural pasca reformasi yang terangkum dalam bentuk budaya populer, memberikan gambaran hadirnya perubahan narasi terkait konflik identitas di Indonesia, khususnya terkait narasi Tionghoa dan tragedi 1965. Namun, narasi psikokultural sendiri merupakan dinamika sosial yang tidak dapat dihindari. Keduanya akan terus ada selama alur pemikiran masyarakat berkembang. Oleh karena itu, walaupun telah terjadi perubahan ke arah positif, namun narasi identitas sangat rentan untuk ditarik kembali ke ranah konflik. Untuk itu, kesadaran akan konstruksi narasi psikokultural diperlukan untuk memberikan pemahaman akan dinamika identitas di Indonesia.

\section{Daftar Pustaka}

Abdullah, A. (2010). Memutus Mata Rantai Kekerasan Antar Umat Beragama. In Menggugat Tanggung Jawab Agama-Agama Brahamik bagi Perdamaian Dunia. Yogyakarta: Kanisius.

Adam, A. W. (2018). Beberapa Catatan Tentang Historiograi Gerakan 30 September 1965. Archipel, 95, 11-30.

Adjidarma, S. G. (2007). Kalathida. Jakarta: Gramedia Pustaka Utama.

Anderson, B. R. (1991). Imagined Community. London: Verso.

Beittinger-Lee, V. (2009). (Un) Civil Society and Political Change in Indonesia: A Contested Arena. New York: Routledge.

Bellamy, R. (1999). Liberalism and Pluralism: Towards a Politics of Compromise. London: Routledge.

Bohleber, W. (2010). Destructiveness, Intersubjecticity, and Trauma: The Identity Crisis of Modern Psychoanalysis. London: Karnac Books Ltd.

Carey, P. (2008). Orang Cina, Bandar Tol, Candu dan Perang Jawa, Perubahan Persepsi tentang Cina 1755-1825. Jakarta: Komu- 
nitas Bambu.

Chua, A. (2003). World on Fire. London: Arrow Books.

Chudori, L. (2013). Pulang. Jakarta: Kepustakaan Populer Gramedia.

Coppel, C. A. (1994). Tionghoa Indonesia Dalam Krisis. Jakarta: Pustaka Sinar Harapan.

Gitanyali. (2012). Blues Merbabu. Jakarta: Kepustakaan Populer Gramedia.

Gonda, J. (1975). Handbook of Oriental Studies. Section 3 Southeast Asia, Religions. Leiden: BRILL Academic.

Haryanto, S. (2012). Konflik Sosial di Era Reformasi. Masyarakat, Kebudayaan, Politik, 25(4), 299-308.

Hawkins, M. (2009). Violence and the construction of identity: conflict between the Dayak and Madurese in Kalimantan, Indonesia. In The politics of the periphery in Indonesia : social and geographic perspectives. Singapura: National University of Singapore Press.

Juditha, C. (2016). Jurnalisme Damai dalam Konflik Agama di Tolikara di Tempo.co. Jurnal Penelitian Komunikasi Dan Opini Publik, 20(1), 93-110.

Kaufman, S. J. (2001). Modern Hatreds: The Symbolic Politics of Ethnic War. Ithaca and London: Cornell University Press.

Kelman, H. (1995). Contributions of an Unofficial Conflict Resolution Effort to the Israeli-Palestinian Breakthrough. Negotiation Journal, 11, 19-27.

König, A. (2016). Identity Constructions and Dayak Ethnic Strife in West Kalimantan, Indonesia. Journal The Asia Pacific Journal of Anthropology, 17(2), 121-137.

Linenthal, E. T. (2001). Preserving Memories. New York: Arcade Publishing.

Madasari, O. (2012). Maryam. Jakarta: Gramedia Pustaka Utama.

Ng, C. (2013). Dimsum Terakhir. Jakarta: Gramedia Pustaka Utama.

Pamuntjak, L. (2017). Amba. Jakarta: Gramedia Pustaka Utama.

Putu, O. S. (2003). Ia menangis di depan Televisi. Bandung: Ultimus.

Roosa, J. (2008). Dalih Pembunuhan Massal:
Gerakan 30 September dan Kudeta Suharto. Jakarta: Institut Sejarah Sosial Indonesia dan Hasta Mitra.

Ross, M. H. (2007). Cultural Contestation in Ethnic Conflict. New York: Cambridge University Press.

Rosyid, M. (2013). Resolusi Konflik Berlatar Agama: Studi Kasus Ahmadiyah Di Kudus. Fikrah, 1(2), 387-412.

Roy, B. (1994). Making Sense of Social Conflict. Berkeley and Los Angeles: University of California Press.

Schafer, R. (1982). The Relevance of the "Here and Now" Transference Interpretation to the Reconstruction of Early Development. International Journal of Psychoanalysis, 63, 77-82.

Sindhunata, G. P. (2007). Putri Cina. Jakarta: Gramedia Pustaka Utama.

Soedjatmoko. (1972). Menjelang Suatu Politik Kebudayaan. Jakarta: LP3ES.

Suryadinata, L. (2003). Kebijakan Negara Indonesia terhadap Etnik Tionghoa: Dari Asimilasi ke Multikulturalisme? Jurnal Antropologi Indonesia, 71, 1-12.

Sutikno, W. (2010). Nyanyian dalam Kelam. Bandung: Ultimus.

Thung, J. L. (2012). Heterogenitas Orang Keturunan Cina (Tionghoa) di Indonesia Dalam Perspektif Sosial-Budaya. Paradigma: Jurnal Kajian Budaya, 3(1), 4253.

Tornquist, O. (2011). Penghancuran PKI. Jakarta: Komunitas Bambu.

Van Den Berg, H. D. (1952). Dari Panggung Peristiwa Sedjarah Dunia. Groningen: J.B Wolters.

Wang, G. (1976). Are Indonesian Chinese unique?': Some Observations. In J. $A$. C. Mackie (Ed.), The Chinese in Indonesia: Five Essays. Melbourne: Thomas Nelson LTD in association with The Australian Institute of International Affairs.

Weiringa, S. (2003). Lubang Buaya. Jakarta: Metafor Publisher. 